\title{
ANALISIS EFEKTIVITAS PENDAYAGUNAAN ZAKAT PRODUKTIF PADA PROGRAM PEMBERDAYAAN MASYARAKAT DI WILAYAH SUKABUMI (STUDI KASUS: KAMPOENG TERNAK DOMPET DHUAFA)
}

\author{
M ARIF BUDIMAN KASIM \\ Alumni STEI SEBI \\ \& \\ IZZUDDDIN EDI SISWANTO
}

Dosen STEI SEBI

\begin{abstract}
ABSTRAK
Penelitian ini bertujuan untuk mengetahui efektivitas pendayagunaan zakat produktif pada program pemberdayaan masyarakat di Wilayah Sukabumi dan juga untuk mengetahui perubahan apa yang terjadi setelah diadakannya program pemberdayaan masyarakat. Fokus usaha dari pemberdayaan masyarakat di Wilayah Sukabumi adalah peternakan domba. Agar program ini berjalan dengan baik maka diadakan proses pendampingan yang dilakukan selama kurang lebih 2 tahun yaitu dengan melalui proses pelatihan, pembinaan, dan pengawasan. Setelah program pemberdayaan masyarakat tersebut dimandirikan, maka dibentuklah Koperasi Riung Mukti sebagai wadah bagi pengembangan usaha dan kelompok yang telah dibentuk. Pokok permasalahan yang dibahas dalam penelitian ini adalah untuk menjawab Efektivitas pendayagunaan zakat produktif pada program pemberdayaan masyarakat yang ada di wilayah Sukabumi. Untuk mengetahui efektivitas program tersebut, terdapat lima indikator yaitu variabel peningkatan pendapatan, peningkatan kesejahteraan dan peningkatan aset, kemandirian dalam diri peternak, peningkatan etos kerja dan spiritual dan kemandirian kelembagaan. Setelah dilakukan analisa dan perhitungan, hasil dari penelitian ini menunjukkan bahwa pendayagunaan zakat produktif pada program pemberdayaan masyarakat di wilayah Sukabumi telah berjalan efektif dengan tingkat persentase efektivitas sebesar $76,74 \%$. Hal ini menunjukkan bahwa melalui program pemberdayaan masyarakat telah terjadi perubahan yang baik. Baik itu dalam hal peningkatan pendapatan, pengembangan usaha ternak dan pengembangan jaringan usaha yang bekerjasama dengan PT Chevron. Walaupun sudah berjalan dengan baik dan efektif, usaha peternak harus terus dikembangkan khususnya dibidang produksi ternak. Selain itu yang perlu diperhatikan oleh lembaga Kampoeng Ternak adalah agar dapat memberikan pelatihan untuk meningkatkan pemahaman anggota tentang mekanisme berjalannya koperasi. Juga perlu diperhatikan fungsi dan peran pengurus Koperasi Riung Mukti agar bekerja sesuai dengan struktur kepengurusan yang telah ditetapkan.
\end{abstract}

Kata Kunci: Efektivitas, Zakat Produktif, Efektivitas Zakat Produktif 


\begin{abstract}
The aim of this research is to find out the effectiveness of productivity of productive zakah in the program of empowering of society in the region of Sukabumi and also to find out the change of the society after being made the program. The business of the program of empowering of society in the region of Sukabumi is the husbandry of sheep. The program of guidance has been done for about 2 years to make the program runs well through the processes of training, development, and controlling. After the program being made to be self-sufficient, the corporation of Riung Mukti is made to develop the business and to develop the made business group. The discussed main problem in this research is to answer the effectiveness of productivity of productive zakah in the program of empowering of society in the region of Sukabumi. To find out the effectiveness of the program, there are five indicators, they are the variable of increasing income, increasing welfare, and increasing asset, the independence of cattlemen, the increasing of work ethic and spiritual and the independence of institution. The result of this research shows that the program had run effectively with the rate of effectiveness $76,74 \%$. The rate shows, through the program of empowering of society, there was a good change in the society. The changes are the increasing income, the developing animal husbandry, and developing net working by working together with PT Chevron. Even the program had run effectively, the production of livestock should be more developing. Besides that, the training for members of corporation to upgrade the understanding the mechanism of how corporation runs should be more getting attention by the institution of Kampoeng Ternak. Also the function and role of corporation Riung Mukti members should be more managing in order to work as theirs determined jobs.
\end{abstract}

Keywords: Effectiveness, Productive Zakah, Effectiveness of Productive Zakah 


\section{BAB I PENDAHULUAN}

\subsection{Latar Belakang}

Kemiskinan merupakan permasalahan yang masih terus dihadapi oleh bangsa Indonesia. Sampai Maret 2012, tercatat jumlah masyarakat miskin Indonesia sebesar 28,59 juta atau 11,66\% dari jumlah penduduk Indonesia (Badan Pusat Statistik, 2012).

Tabel 0.1 Jumlah dan Presentase Penduduk Miskin Indonesia

\begin{tabular}{|l|l|l|}
\hline Tahun & $\begin{array}{l}\text { Jumlah Penduduk } \\
\text { Miskin } \\
\text { (Juta orang) }\end{array}$ & $\begin{array}{l}\text { Persentase Penduduk } \\
\text { Miskin \% }\end{array}$ \\
\hline 2008 & 34,96 & 15,42 \\
\hline 2009 & 32,53 & 14,15 \\
\hline 2010 & 31,02 & 13,33 \\
\hline 2011 & 30,02 & 12,49 \\
\hline 2012 (September) & 28,59 & 11,66 \\
\hline
\end{tabular}

Sumber : Badan Pusat Statistik 2012

Dari Tabel di atas menunjukkan bahwa jumlah masyarakat miskin Indonesia masih sangat begitu besar, walaupun terjadi penurunan angka kemiskinan disetiap tahunnya. Hal ini tetap menjadi pekerjaan rumah yang sangat berat bagi pemerintah Indonesia untuk terus meningkatkan kesejahteraan bagi masyarakat Indonesia. Tentunya kesejahteraan tersebut dapat dicapai dengan dukungan masyarakat Indonesia itu sendiri untuk terus bekerja keras mencapai kesejahteraan bersama.

Islam memandang kemiskinan merupakan satu hal yang mampu membahayakan akidah, akhlaq, kelogisan berfikir, keluarga dan juga masyarakat. Islam pun menganggapnya sebagai musibah dan bencana yang harus di tanggulangi. Jika kemiskinan ini sudah merajalela, ia akan menjadi kemiskinan yang mansiyyan (mampu membuatnya lupa kepada Allah dan juga kemanusiaannya). (Yusuf Qardhawi, 2006). Salah satu penanggulangan kemiskinan tersebut adalah dengan dibuatnya mekanisme yang mampu mengalirkan kekayaan dari kelompok masyarakat mampu (the have) kepada kelompok masyarakat yang tidak mampu (the have not). Zakat, sebagai rukun Islam yang ketiga, merupakan instrument utama yang dimiliki oleh Islam, yang berfungsi sebagai distributor aliran kekayaan dari kelompok yang mampu kepada kelompok yang tidak mampu. Zakat merupakan institusi resmi yang diarahkan untuk menciptakan pemerataan dan keadilan bagi masyarakat, Sehingga taraf hidup masyarakat dapat ditingkatkan. (Hafidhuddin, 2006).

Studi terbaru yang dilakukan oleh Baznas dan Fakultas Ekonomi Manajemen (FEM) IPB tahun 2011 menunjukkan banwa potensi zakat nasional mencapai angka 3,40 persen dari PDB atau tidak kurang dari Rp.217 Triliun (Membangun Peradaban Zakat Indonesia: Soal Kebijakan dan Hal Lain yang Belum Paripurna, 2012). Dalam pelaksanaannya, zakat 
harus diatur oleh agama dan negara, baik yang memberikan zakat (Muzakki), penerima zakat (Mustahik), harta yang dizakati, dan pengelolaan zakat. (Megawati, 2010).

Saat ini pendayagunaan zakat secara produktif sedang mengalami kemajuan pesat, karena dari pelolaan zakat secara produktif mampu memberikan hasil yang lebih optimal untuk meningkatkan kesejahteraan masyarakat. Pendayagunaan secara produktif haruslah terus didukung dengan maksimal karena menurut penelitian yang dilakukan oleh Pusat Ekonomi dan Bisnis Syariah Fakultas Ekonomi Universitas Indonesia (PEBS-FEUI) dan Indonesia Magnificence Zakat (IMZ), pengunaan dana untuk program ekonomi produktif masih tergantung dengan alokasi bagi program lain. Hal ini terlihat pada tahun 2004 ketika kebutuhan dana kemanusian relatif rendah $(11,5 \%)$ maka proporsi yang diberikan untuk kegiatan ekonomi produktif cenderung tinggi, yaitu 20,3\%. Sebaliknya pada tahun 2005, ketika kebutuhan dan alokasi untuk dana kemanusiaan melonjak tinggi sebesar 49,8\%, alokasi yang diperuntukkan bagi ekonomi produktif turun menjadi 9\%. Namun demikan pada tahun-tahun selanjutnya, terlihat bahwa alokasi untuk program ekonomi produktif cenderung stabil di bawah 10\% (Menggagas Arsitektur Zakat Nasional: Menuju Sinergi Pemerintah dan Masyarakat Sipil Dalam Pengelolaan Zakat Nasional, 2010).

Salah satu lembaga yang menerapkan pendayagunaan zakat secara produktif adalah Lembaga Amil Zakat Dompet Dhuafa. Setiap tahunnya, Dompet Dhuafa terus meningkatkan kinerjanya, baik dalam penghimpunan zakat maupun dalam pendayagunaan zakat tersebut. Salah satu program yang dilaksanakan adalah program Kampoeng Tenak Nusantara yaitu program distribusi zakat secara produktif melalui pemberdayaan masyarakat. Kampoeng Ternak Nusantara adalah jejaring enterprise Dompet Dhuafa yang melakukan pengembangan berbasis pemberdayaan masyarakat secara berkelanjutan dan memberi manfaat secara langsung bagi masyarakat miskin atau dhuafa. Hingga saat ini program Kampoeng Ternak telah menjangkau hingga 17 daerah diantaranya ialah Tasikmalaya, Sumedang, Garut, Sukabumi, Karawang, Tuban, Situbondo, Bima, Lampung, Okut, dan Parung Bogor. Jumlah mustahik yang telah mengikuti program ini secara langsung sebanyak 900 orang dan yang tidak mengikuti program ini secara tidak langsung kurang lebih melibatkan 3000 mustahik.

Dengan adanya program Kampoeng Ternak dan kendala yang terjadi di dalam program ini, maka peneliti tertarik untuk melakukan penelitian sejauh mana tingkat keefektivitasan zakat produktif yang telah diterapkan oleh Lembaga Dompet Dhuafa pada program Pemberdayaan Masyarakat melalui Ternak Domba yang ada di Wilayah Sukabumi. Selain itu penelitian ini dilakukan untuk mengetahui apakah program ini berjalan dengan baik atau sebaliknya, terlebih lagi setelah dilakukan pembinaan dan pendampingan yang dilakukan oleh Lembaga Kampoeng Ternak Dompet Dhuafa. Karena dana program tersebut adalah dana zakat 
yang perlu untuk dipertanggung jawabkan. Untuk mengetahui keefektivitasannya terdapat beberapa indikator penelitian yang di tetapkan oleh Kampoeng Ternak yaitu:

1. Peningkatan Pendapatan.

2. Peningkatan kepemilikan Aset Produktif.

3. Terbagunnya kemandirian dalam diri peternak.

4. Penigkatan etos kerja dan Spiritual.

5. Terbangunnya kemandirian kelembagaan dalam komunitas peternak.

Berdasarkan penjelasan diatas penulis tertarik untuk melakukan penelitian zakat dengan menggunakan metode zakat produktif dengan judul "Analisis Efektivitas Pendayagunaan Zakat Produktif Pada Program Pemberdayaan Masyarakat di Wilayah Sukabumi" (Studi Kasus Kampoeng Ternak Nusantara Dompet Dhuafa).

\subsection{Rumusan Masalah}

Salah satu Lembaga Zakat yang mengembangkan program ekonomi produktif adalah Dompet Dhuafa, melalui program pemberdayaan masyarakat melalui ternak Domba. Akan tetapi, tidak semua yang dijalankan selalu berjalan dengan baik, karena dalam program ini pun masih terdapat masalah yang terjadi sehingga perlu dibenahi dan dilakukan pembinaan. Melalui penelitiaan ini, diharapkan dapat diketahui seberapa efektifkah pedayagunaan zakat produktif pada Program Pemberdayaan Masyarakat melalui Ternak Domba di Wilayah Sukabumi. Dari penjelasan tersebut peneliti mengidentifikasi beberapa masalah yang terjadi, sebagai berikut:

1. Untuk mengetahui efektivitas pendayagunaan zakat produktif pada program pemberdayaan masyarakat yang ada di Wilayah Sukabumi Kecamatan Kelapa Nunggal.

\subsection{Pembatasan Masalah}

Berdasarkan identifikasi masalah diatas, penulis akan membatasi ruang lingkup pembahasan dan penelitiannya pada penerapan dan pendayagunaan zakat produktif yang dilakukan oleh Masyarakat di Wilayah Sukabumi Kecamatan Kelapa Nunggal pada program Pemberdayaan Masyarakat Melalui Ternak Domba apakah sudah efektif atau belum. 


\section{BAB II LANDASAN TEORI}

\subsection{Konsep Zakat}

Zakat adalah ibadah Maaliyah Ijtimaiyyah yang memiliki posisi yang penting, strategis dan menentukan, baik dari sisi ajaran maupun dari sisi pembangunan kesejahteraan umat. Sebagai suatu ibadah pokok, zakat termasuk salah satu rukun Islam, Sebagaimana yang diungkapkan dalam berbagai Hadist Nabi, sehingga keberadaanya dianggap ma'lum min addien bi adl-dlurah atau di ketahui secara tomatis adanya dan merupakan bagian mutlak dari keislaman seseorang. (Hafidhuddin,2006)

Sebagai seorang yang beriman, pemberian zakat haruslah dilaksanakan secara sukarela atau dengan niat yang tulus ikhlas. Karena Allah SWT begitu jelas menjelaskan bahwa menunaikan zakat tidaklah mengurangi dari harta yang dimiliki, akan tetapi sebaliknya, dengan menunaikan zakat maka harta yang kita miliki menjadi lebih berkah dan terus bertambah.

'Abdullah Yusuf Ali, menerangkan dan menjelaskan pandangan Islam yang menyeluruh tentang zakat, mengatakan:

Karunia ini-yang Allah berikan kepada manusia karena kebesaran-Nya — adalah segala hal. Ada yang berupa materi seperti kekayaan, kekuatan anggota tubuh dan lain-lain. Ada juga pemberian yang tak terindra seperti keahlian, wawasan, dan lainlain. Bisa juga pemberian itu berupa spiritualitas tertinggi. Pengguna segala karunia ini kelebihan dari apa yang kita perlukan merupakan untuk diri sendiri-untuk mereka yang memerlukan merupakan sedekah. Segala yang diberikan itu menyucikan hati kita. Sebaliknya, menahannya tanpa memberikan kepada orang lain-kelebihan dari yang kita butuhkan-merupakan ketamakan dan kerakusan yang sangat dikutuk. (al-Syaikh, 2008, p. 13)

Jadi dapat disimpulkan bahwa zakat adalah kewajiban yang harus dikeluarkan oleh seorang muslim dengan kriterian dan syarat yang telah ditentukan baik nisyab dan masa haulnya. Zakat tidaklah mengurangi harta akan tetapi zakat akan menjadikan harta yang dimiliki menjadi berkah dan bertambah. Zakat juga memberikan arti bahwa terdapat rasa social yang mendalam didalamnya. Dimana kaum kaya dapat memberikan sebagian dari harta yang dimiliki kepada kaum dhuafa untuk dapat dimanfaatkan dengan sebaik baiknya. Selanjutnya akan dibahas pengertian zakat.

\subsubsection{Pengertian Zakat}

Dari segi bahasa, kata zakat mempunyai beberapa arti, yaitu albarakatu 'keberkahan', al-namnaa 'pertumbuhan dan perekembangan', ath-thaharatu 'kesucian', dan ash-shalahu 'keberesan'. Sedangkan secara istilah meskipun para ulama memiliki redaksi yang berbeda antara satu dengan yang lainnya, akan tetapi pada hakikatnya memiliki prinsip yang sama, yaitu bahwa zakat itu adalah bagian harta dengan persyaratan tertentu, yang Allah SWT mewajibkan kepada pemiliknya untuk 
diserahkan kepada yang berhak menerimanya, dengan persyaratan tertentu pula (Hafidhuddin, 2002).

Zakat adalah salah satu instrumen yang menciptakan pertumbuhan buat orang-orang miskin. Zakat adalah cambuk ampuh yang membuat zakat tidak hanya menciptakan pertumbuhan material dan spiriritual bagi orang-orang miskin, tetapi juga mengembangkan jiwa dan kekayaan orang-orang kaya (Qardhawi, 1987). Selain itu zakat ada istilah sedekah dan infak, sebagian ulama fiqh mengatakan bahwa sedekah wajib itu dinamakan dengan zakat, sedangkan sedekah sunnah itu dinamakan dengan infak. Sebagian lain juga mengatakan infak wajib itu dinamakan zakat, sedangkan infak sunnah dinamakan dengan sedekah. (Bariadi, Zen, \& Huri, 2006).

Dalam kitab-kitab hukum Islam, perkataan zakat itu diartikan dengan suci, tumbuh dan berkembang serta berkah, dan jika dihubungkan dengan harta, maka menurut ajaran agama Islam, harta yang dizakati akan tumbuh berkembang, bertambah karena suci dan berkah (membawa kebaikan bagi hidup dan kehidupan yang punya). Jika dirumuskan, maka zakat adalah bagian dari harta yang wajib diberikan oleh setiap muslim yang memenuhi syarat- syarat tertentu pula. Syarat-syarat itu ialah nisab, haul dan kadarnya (Ali, 2006).

\subsubsection{Prinsip-prinsip Zakat}

Menurut Mannan dalam bukunya Islamic Economics: Theory and Paractice (Lahore, 1970 : 285), zakat mempunyai enam prinsip, yaitu (1) prinsip keyakinan agama (faith), (2) prinsip pemerataan (equty) dan keadilan, (3) prinsip produktivitas (productivity) dan kematangan (4) prinsip nalar (reason), (5) prinsip kebebasan (freedom), (6) prinsip etik (ethic) dan kewajaran.

\subsubsection{Dasar Hukum Zakat}

Zakat adalah salah satu rukun Islam yang lima. Zakat merupakan salah satu kewajiban yang ada didalamnya. Zakat diwajibkan di Madinah pada Bulan Syawal Tahun Kedua Hijriah. Kewajiban ini dilaksanakan setelah puasa Ramadhan dan zakat fitrah. Tetapi zakat tidak di wajibkan atas para Nabi. Pendapat yang terakhir ini di setujui oleh para ulama karena salah satu fungsi zakat adalah sebagai pembersih dari dosa - dosa. Sedangkan Nabi terbebas dari hal yang demikian.

\section{a. Al-Quran}

Zakat dalam Al-Quran disebutkan sebanyak $82 \mathrm{kali}$, hal ini menunjukkan bahwa dasar hukum zakat yang sangat kuat, antara lain dalam Qs. Al Baqarah ayat 43:

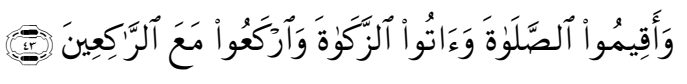

Artinya: Dan laksanakanlah shalat, tunaikanlah zakat dan rukuklah beserta orang-orang yang rukuk. 
Dijelaskan juga dalam Qs: At-Taubah ayat 11 :

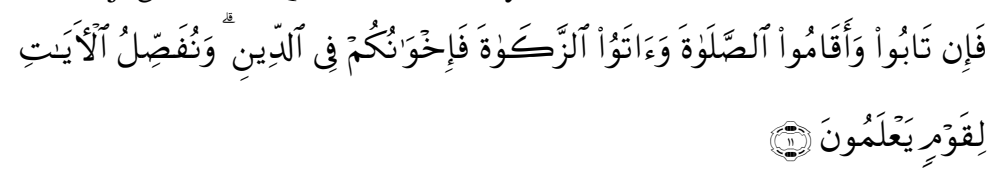

Artinya: Dan jika mereka bertaubat, melaksanakan sholat dan menunaikan zakat, Maka (berarti mereka itu) adalah saudarasaudaramu seagama. Kami menjelaskan ayat-ayat itu bagi orangorang yang mengetahui.

b. As-sunnah

Adapun dasar hukum berdasarkan sunnah yaitu :

Diriwayatkan dari Ibnu Abbas r.a dan jamaah bahwa takkala Nabi mengutus Muadz bin Jabal r.a untuk menjadi Qadhi di Yaman, beliau bersabda:

"Engkau akan mendatangi suatu kaum dari golongan ahli kitab. Langkah awal yang mesti kau dilakukan, hendaklah engkau menyeru mereka untuk mengetahui bahwa tiada tuhan selain Allah SWT dan bahwa aku adalah utusan Allah SWT. Telah mewajibkan mereka supaya mengerjakan shalat lima waktu dalam sehari semalam. Jika hal tersebut telah mereka taati, sampaikanlah bahwa Allah SWT telah mewajibkan zakat pada harta benda mereka yang dipungut dari orang-orang kaya diberikan kepada orang miskin diantara mereka. Jika hal ini telah mereka penuhi, hendaklah engkau menghindari harta benda mereka yang berharga. Hindarilah doa orang yang teraniaya karena tidak terbatas tabir antara dirinya dan Allah SWT".

Dalam kitab Ausaht dan As Shaghir, Tabrani meriwayatkan dari Ali R.A. bahwa Nabi SAW telah bersabda:

"Allah SWT telah mewajibkan zakat kepada harta orang-orang kaya kaum muslimin sejumlah yang dapat memberikan jaminan kepada orangorang miskin dikalangan mereka. Fakir miskin tidak akan menderita kelaparan dan kesulitan sandang pangan melainkan disebabkan perbuatan golongan kaya. Ingatlah bahwa Allah SWT akan mengadili mereka secara tegas dan menyiksa mereka dengan azab yang pedih akibat perbuatannya".

Ahmad Tirmidzi meriwayatkan dari Abu Hurairah Rosulullah SAW bersabda: "Sesungguhnya Allah SWT menerima zakat dan mengambilnya dengan tangan kanan lalu mengasuhnya untuk si pemberi sebagaimana salah salah seorang mengasuh anak kudanya hingga sesuap nasi akan menjadi sebesar bukit”.

\section{c. Hukum Positif}

Pemerintah sebagai intitusi tertinggi telah mengatur undangundang yang mejelaskan tentang praktek zakat di Indonesia yang tetuang pada Undang-Undang Republik Indonesia No 23 tahun 2011 yang menjelaskan tentang pengelolaan zakat. Pasal 1 pada BAB 1 ketentuan 
umum menjelaskan tentang pengelolaan zakat, pengertian dari zakat, infak, sedekah, mustahik dan muzakki, Badan Amil Zakat Nasional, Lembaga Amil Zakat, Unit Pengelolaan Zakat, Hak Amil.

\subsubsection{Pengertian Zakat Produktif}

Zakat produktif adalah pemberian zakat yang bisa menjadikan para penerimanya menghasilkan sesuatu secara terus menerus, dengan harta zakat yang telah diberikan. Dengan demikian zakat produktif adalah zakat dimana harta zakat tidak dihabiskan dalam satu waktu akan tetapi dikembangkan sehingga hasilnya bisa dinikmati terus menerus (Asnaini, Zakat Produktif dalam Prespektif Hukum Islam, 2008).

Kelemahan utama orang miskin serta usaha kecil yang dikerjakannya sesungguhnya tidak semata-mata pada kurangnya permodalan, tetapi lebih pada sikap mental dan kesiapan manajemen usaha. Untuk itu, zakat usaha produktif pada tahap awal harus mampu mendidik mustahiq sehingga benar-benar siap untuk berubah. Karena tidak mungkin kemiskinan itu dapat berubah kecuali dimulai dari perubahan mental si miskin itu sendiri. Inilah yang disebut peran pemberdayaan. Zakat yang dapat dihimpun dalam jangka panjang harus dapat memberdayakan mustahiq sampai pada dataran pengembangan usaha. program-program yang bersifat konsumtif ini hanya berfungsi sebagai stimulan atau rangsangan dan berjangka pendek., sedangkan program pemberdayaan ini harus diutamakan. Makna pemberdayaan dalam arti yang luas ialah memandirikan mitra, sehingga mitra dalam hal ini mustahiq tidak selamanya tergantung kepada amil (Sartika, 2008).

\subsubsection{Hukum Zakat Produktif}

Sebagaimana yang telah dijelaskan sebelumnya bahwa yang dimaksud dengan zakat produktif adalah pendayagunaan zakat secara produktif. Alquran, hadist, dan ijma' ulama tidak menyebutkan secara tegas tentang cara pendistribusian zakat baik itu dilakukan secara konsumtif maupun secara produktif (Megawati, 2011). Dengan demikian tidak ada dalil naqli yang secara sharih yang mengatur tetang bagaimana pemberian zakat kepada mustahik.

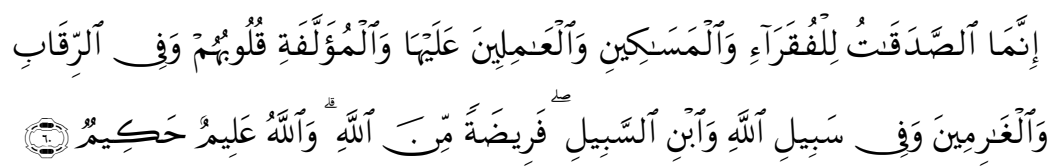

Artinya: Sesungguhnya zakat itu hanyalah untuk orang-orang fakir, orang miskin, amil zakat, yang dilunakkan hatinya (muallaf), untuk (memerdekakan) hamba sahaya, untuk (membebaskan) orang yang berhutang, untuk jalan Allah dan orang yang sedang dalam perjalanan, sebagai kewajiban dari Allah, Allah Maha mengetahui, Maha Bijaksana.

Sebagaimana dengan dalil Al-Quran surat At-Taubah ayat 60 diatas yang menjelaskan tentang pos-pos penerima zakat. Sebagian ulama menjadikan ayat ini sebagai dasar hukum zakat produktif yaitu untuk 
melihat siapa saja yang berhak menerima dana zakat tersebut baik secara konsumtif maupun produktif, dengan syarat, pemberian tersebut tetap diberikan kepada 8 asnaf yang berhak. Ayat ini menjelaskan tetang kepada siapa saja dana zakat ini diberikan, dan tidak menyebutkan cara pemberian zakat tersebut kepada pos-pos tersebut (Asnaini, Zakat Produktif dalam Prespektif Hukum Islam, 2008). Selanjutnya akan dibahas konsep zakat produktif.

\section{BAB III METODOLOGI PENELITIAN}

\subsection{Metode Penelitian}

Dalam penulisan ini, metode penelitian yang akan digunakan oleh penulis adalah metode kombinasi Concurrent Triangulation, yaitu metode yang menggabungkan antara metode kualitatif dan kuantitatif dengan cara mencampur kedua metode tersebut secara seimbang. Pada penelitian dengan menggunakan metode ini difokuskan pada teknik pengumpulan data dan analisa data, sehingga peneliti dapat menganalisa apakah kedua data tersebut memperkuat, memperlemah atau bertentangan. (Sugiyono,2011)

\section{Lokasi Penelitian}

Penelitian ini dilakukan pada Lembaga Amil Zakat Dompet Dhuafa yaitu Kampoeng Ternak Nusantara. Program ini dilaksanakan di Wilayah Sukabumi Kecamatan Kelapa Nunggal di Desa Palasari Girang, Desa Pulo Sari Girang, Desa Walang Sari dan di Kecamatan Kebandungan Desa Tugu Bandung.

\subsection{Populasi dan Sampel}

Populasi adalah wilayah yang genealisasi yang terdiri atas obyek/subyek yang mempunyai kualitas dan karakteristik tertentu yang ditetapkan oleh peneliti untuk dipelajari dan kemudian ditarik kesimpulannya. (Sugiono,2009) Populasi dari penelitian ini adalah mustahik yang tergabung dalam program Kampoeng Ternak yang berjumlah 73 Mustahik. Sedangkan teknik sampel yang digunakan adalah Simple Random Sampling yaitu dengan mengambil anggota sampel dari populasi secara random yang tergabung dan berkaitan dalam program pemberdayaan masyarakat. Jumlah sampel yang peneliti dapat adalah sebanyak 47 mustahik.

\subsection{Sumber Data}

Dalam penelitian ini, penulis akan menggunakan dua sumber data, yaitu data primer dan data Sekunder. 


\section{a. Data Primer}

Data Primer yaitu data yang dikumpulkan sendiri oleh peneliti langsung dari sumber pertama, adapun cara untuk mendapatkan data primer, yaitu dengan cara meninjau langsung perusahaan yang menjadi objek penelitian, teknik penelitiannya dengan cara wawancara, kuisioner dan observasi.

\section{b. Data sekunder}

Data Sekunder yaitu data yang diterbitkan atau digunakan oleh seseorang yang bukan pengolahnya. Teknik yang digunakan dalam memperoleh data ini adalah: Studi Kepustakaan, misalnya: dari buku panduan, literatur, dan bahan-bahan perkuliahan yang memiliki kaitan erat dengan pembahasan ini. Dokumentasi, misalnya: mengutip langsung data yang diperoleh dari perusahaan.

\subsection{Teknik Pengumpulan Data}

\section{a. Studi Kepustakaan}

Pada tahap ini penulis akan melakukan pengumpulan data melalui studi kepustakaan baik yang bersumber dari media cetak, internet maupun dokumen -dokumen terkait yang dimiliki oleh Kampoeng Ternak Dompet Dhuafa.

\section{b. Studi Lapangan}

Pada tahap ini penulisan dilakukan secara langsung pada Kampoeng Ternak Dompet Dhuafa sebagai objek penelitian dengan cara:

1. Wawancara, yaitu teknik pengumpulan data yang dilakukan dengan cara Tanya jawab langsung dengan pihak Kampoeng Ternak, mitra Kampoeng Ternak dan pihak Koperasi Serba Usaha Riung Mukti .

2. Dokumentasi, yaitu teknik pengumpulan data dengan cara mengumpulkan data-data yang diperlukan dengan mendapatkannya dari Kampoeng Ternak.

3. Kuisioner (angket), yaitu teknik pengumpulan data dengan cara memberi seperangkat pertanyaan atau pernyataan secara tertulis kepada responden untuk dijawabnya. (Sugiyono, Metodelogi Penelitian Kuantitatif Kualitatif dan R \& D, 2009). Kuisioner ini ditujukan kepada seluruh mitra yang tergabung dalam program pemberdayaan masyarakat melalui ternak domba yang berada di Wilayah Sukabumi, Kecamatan Kelapa Nunggal dengan jumlah mitra mengisi kuisioner sebanyak 47 mitra.

4. Observasi, teknik pengumpulan data observasi lapangan adalah untuk mebuktikan secara lebih rill untuk menguatkan data-data sebelumnya dengan melihat secara langsung peningkatan dan perubahan yang terjadi setelah diadakannya program pemberdayaan masyarakat yang ada di wilayah Sukabumi. 


\subsection{Instrumen Penelitian}

Dalam penelitian ini peneliti memiliki instrument penelitian dengan lima variabel dan indikator yang ditujukan untuk mengetahui efektivitas pendayagunaan zakat produktif pada program pemberdayagunaan masyarakat melalui ternak domba. Berikut variabel dan indikator yang telah ditentukan dan diterima indikatornya oleh Bapak Zainudin dari Lembaga Kampoeng Ternak:

Tabel 0.1 Variabel Penelitian

\begin{tabular}{|c|c|c|}
\hline No & Variabel & Indikator \\
\hline 1 & $\begin{array}{l}\text { Peningkatan } \\
\text { pendapatan }\end{array}$ & $\begin{array}{l}\text { 1. Petenak mampu meningkatkan pendapatan } \\
\text { melalui program Kampoeng Ternak ini. } \\
\text { 2. Kelompok ternak menjadikan program ini } \\
\text { sebagai pekerjaan tetap sehingga peternak } \\
\text { mampu meningkatkan pendapatnnya } \\
\text { 3. Kelompok ternak diharapkan mampu } \\
\text { berinovasi sehingga pendapatan terus } \\
\text { meningkat }\end{array}$ \\
\hline 2 & $\begin{array}{l}\text { Peningkatkan } \\
\text { kesejahteraan dan } \\
\text { peningkatan aset } \\
\text { produktif }\end{array}$ & $\begin{array}{ll}\text { 4. } & \text { Terbentuknya motivasi peternak untuk } \\
\text { meningkatkan kesejahteraan hidupnya. } \\
\text { 5. } \\
\text { Peternak mampu meningkatkan aset } \\
\text { produktif. } \\
\text { 6. Peternak mampu mengembangkan aset } \\
\text { produktif. } \\
\text { 7. Pemberian dana yang diberikan lembaga } \\
\text { Kampoeng Ternak Nusantara mampu } \\
\text { meningkatkan kesejahteraan mitra. }\end{array}$ \\
\hline 3 & $\begin{array}{l}\text { Terbangunnya } \\
\text { kemandirian dalam } \\
\text { diri peternak }\end{array}$ & $\begin{array}{l}\text { 8. } \\
\text { 9. Peternak memiliki usaha di luar usaha inti. } \\
\text { peternak selalu mencatat hasil penjualan } \\
\text { 10. Para peternak mampu menjual langsung atau } \\
\text { melalui jaringan yang telah dibuat oleh } \\
\text { lembaga. }\end{array}$ \\
\hline 4 & $\begin{array}{l}\text { Peningkatan etos } \\
\text { kerja dan spiritual }\end{array}$ & $\begin{array}{l}\text { 11. Peternak mampu untuk terus meningkatkan } \\
\text { kinerja } \\
\text { 12. Peternak mampu berkerja secara profesional } \\
\text { 13. Peternak mampu meningkatkan tingkat } \\
\text { spiritual mereka. } \\
\text { 14. Peternak mampu menciptakan budaya kerja } \\
\text { yang Islami (jujur, amanah, dan professional) }\end{array}$ \\
\hline 5 & $\begin{array}{l}\text { Kemandirian } \\
\text { kelembagaan }\end{array}$ & $\begin{array}{l}\text { 15. Peternak mampu berperan aktif dalam } \\
\text { pembangunan Koperasi Riung Mukti } \\
\text { 16. Koperasi Riung Mukti mampu menjadi } \\
\text { penghubung antara peternak dengan Lembaga } \\
\text { Kampoeng Ternak Nusantara. }\end{array}$ \\
\hline
\end{tabular}




\subsection{Analisis Data}

\section{a. Analisa Kuantitaif}

\section{Uji Validitas}

Validitas adalah suatu ukuran yang menunjukkan tingkat-tingkat kevalidan atau kesahihan sesuatu instrument. Suatu instrumen yang valid atau sahih mempunyai validitas yang tinggi. Sedangkan instrument yang kurang valid berarti memiliki validitas yang rendah. Sebuah intrumen dikatakan valid apabila mampu mengukur apa yang diinginkan dan juga dapat mengungkapkan data dari variabel yang diteliti secara tepat.

Dalam penelitian ini, peneliti menggunakan intrumen berupa kuisioner untuk mengukur varibel yang akan diteliti. Variabel yang akan diteliti yaitu mengenai efektivitas, maka validitas construct menjadi pilihan untuk melakukan uji tersebut. Validitas kontrak adalah merupakan konsep pengukuran validitas dengan cara menguji apakah suatu instrument mengukur constract sesuai dengan yang diharapkan. Validitas dalam penelitian ini akan diukur dengan menggunakan korelasi Product Moment yaitu dengan rumus sebagai berikut: (Sunyoto \& Danang, 2011)

Rumus:

$$
r=\frac{\sum(X i-\bar{X})(Y i-\bar{Y})}{\sqrt{\sum(X i-\bar{X})^{2} \sum(Y i-\bar{Y})^{2}}}
$$

Dimana :

$\mathrm{r} \quad=$ Koofesien Korelasi Product Moment

$\mathrm{Xi} \quad=$ Skor tiap butir pertanyaan

$\mathrm{Yi}=$ Skor tiap total responden

$\mathrm{XiYi}=$ Skor tiap butir pertanyaan dikalikan skor total tiap responden

$\mathrm{n} \quad=$ Jumlah Responden

Taraf signifikan ditentukan $\alpha=5 \%$, jika diperoleh hasil yang lebih besar dari $r$ table pada taraf siginfikan $\alpha=5 \%$, berarti butir pertanyaan tersebut valid.

\section{Uji Reabilitas}

Reabilitas menunjukan pada suatu pengertian bahwa sesuatu instrument cukup dipercaya untuk digunakan sebagai alat pengumpul data karena instrument tersebut sudah baik. Instrument yang baik tidak akan bersifat tendensius mengarahkan responden untuk memilih jawabanjawaban tertentu. Intrumen yang dipercaya, yang reliable akan mengahasilkan data yang dapat dipercaya jua. Apabila datanya benar sesuai dengan kenyataannya, maka berapa kalipun diambil, tetap akan sama. Reablitas menunjukkan pada tingkat keterandalan sesuatu. Karena pada makna reliable berarti, dapat dipercaya, jadi dapat diandalkan.

Uji reabilitas dilakukan dengan menggunakan metode Cronbach's Alpha menggunakan bantuan SPSS 18.0 for Windows. 


\section{Uji t}

Setelah data yang dibutuhkan terkumpul, maka untuk menguji keefektivitasan program zakat produktif data jawaban kuisioner responden akan diuji dan diolah kemudian dianalisi dengan menggunakan teknik analisis t-test one sample, dengan uji pihak kiri. (Sugiono, Statistik Untuk Penelitian, 2012)

Rumus: $t=\frac{\bar{X}-\mu 0}{(s / \sqrt{n})}$

Keterangan :

$\mathrm{T}=$ Nilai yang dihitung

$\mathrm{x} \quad=$ rata-rata

$\mu 0 \quad=$ Nilai yang dihipotesiskan

n = Jumlah sampel

Untuk menguji Hipotesis dalam penelitian ini akan dilakukan langkahlangkah sebagai berikut:

Data yang diperoleh adalah jawaban responden terhdap kuisioner, dimana setiap jawaban akan diberi skor sebagai berikut:

Sangat Setuju $\quad=4$

Setuju $\quad=3$

Tidak Setuju $\quad=2$

Sangat Tidak Setuju $=1$

Setelah data kuisioner diolah maka akan dilakukan uji sample t test untuk menguji Hipotesis.

\section{Uji Statistik Non Parametrik Wilxocon Signed Rank Test}

Uji Statistik Non Parametrik Wilxocon adalah uji dua sampel yang saling berpasangan atau berhubungan. Yang dimaksud berpasangan atau berhubungan adalah subjek yang diukur sama, namun diberi dua macam perlakuan. Pengujian ini menggunakan SPSS 18.0 Windows.

Dalam hal ini mitra Kampoeng Ternak mendapatkan dua perlakuan yang berbeda yaitu pendapatan sebelum program dan pendapatan setelah program. Selain itu, uji statistik ini dilakukan untuk menjawab Hipotesis pada Variabel Peningkatan Pendapatan.

\section{Peningkatan Pendapatan}

Pada variabel pendapatan terdapat dua hipotesis yang akan diuji yaitu:

1. Efektivitas Program sama atau diatas $75 \%$

Ho $: \mu \geq 75 \%$ Ho diterima atau tidak ditolak, yang berarti bahwa pendayagunaan zakat produktif dalam Program Pemberdayaan Masyarakat Melalui Ternak Domba di Kampoeng Ternak Nusantara sudah efektif.

H1 $: \mu<75 \%$ H1 ditolak yang berarti bahwa pendayagunaan zakat produktif dalam Program Pemberdayaan Masyarakat Melalui Ternak Domba di Kampoeng Ternak Nusantara belum efektif. 
2. Peningkatan Pendapatan Melalui Uji Wilcoxon

Ho : Tidak terjadi perubahan peningkatan pendapatan pada mitra melalui Program Pemberdayaan Masyarakat Melalui Ternak Domba di Kampoeng Ternak Nusantara.

H1 : Terjadi perubahan peningkatan pendapatan pada mitra melalui Program Pemberdayaan Masyarakat Melalui Ternak Domba di Kampoeng Ternak Nusantara.

\section{Peningkatan Kesejahteraan dan Peningkatan Aset Produktif}

Ho $\quad: \mu \geq 75 \%$ Ho diterima atau tidak ditolak, yang berarti bahwa telah terjadi Peningkatan Kesejahteraan dan Peningkatan Aset Produktif melalui program pendayagunaan zakat produktif dalam Program Pemberdayaan Masyarakat Melalui Ternak Domba di Kampoeng Ternak Nusantara sudah efektif.

H1 : $\mu<75 \%$ H1 ditolak yang berarti bahwa. tidak terjadi Peningkatan Kesejahteraan dan Peningkatan Aset Produktif melalui program pendayagunaan zakat produktif dalam Program Pemberdayaan Masyarakat Melalui Ternak Domba di Kampoeng Ternak Nusantara belum efektif.

\section{Terbangunnya Kemandirian Dalam Diri Peternak}

Ho $\quad: \mu \geq 75 \%$ Ho diterima atau tidak ditolak, yang berarti bahwa telah terjadi Kemandirian dalam diri peternak untuk melakukan usaha ternaknya melalui program pendayagunaan zakat produktif dalam Program Pemberdayaan Masyarakat Melalui Ternak Domba di Kampoeng Ternak Nusantara sudah efektif.

$\mathrm{H} 1 \quad: \mu<75 \% \mathrm{H} 1$ ditolak yang berarti bahwa. tidak terjadi Kemandirian dalam diri peternak untuk melakukan usaha ternaknya melalui program pendayagunaan zakat produktif dalam Program Pemberdayaan Masyarakat Melalui Ternak Domba di Kampoeng Ternak Nusantara belum efektif.

\section{Peningkatan Etos Kerja dan Spiritual}

Ho $\quad: \mu \geq 75 \%$ Ho diterima atau tidak ditolak, yang berarti bahwa telah terjadi peningkatan etos kerja dan tingkat spiritual melalui program pendayagunaan zakat produktif dalam Program Pemberdayaan Masyarakat Melalui Ternak Domba di Kampoeng Ternak Nusantara sudah efektif.

H1 : $\mu<75 \%$ H1 ditolak yang berarti bahwa. tidak terjadi peningkatan etos kerja dan tingkat spiritual melalui program pendayagunaan zakat produktif dalam Program Pemberdayaan Masyarakat Melalui Ternak Domba di Kampoeng Ternak Nusantara belum efektif. 


\section{Kemandirian Lembaga}

Ho $\quad: \mu \geq 75 \%$ Ho diterima atau tidak ditolak, yang berarti bahwa telah terjadi kemandirian kelembagaan pada koperasi riung mukti setelah melalui program pendayagunaan zakat produktif dalam Program Pemberdayaan Masyarakat Melalui Ternak Domba di Kampoeng Ternak Nusantara sudah berjalan efektif.

H1 $: \mu<75 \%$ H1 ditolak yang berarti bahwa. tidak terjadi kemandirian keembagaan pada Koperasi Riung mukti setelah melalui program pendayagunaan zakat produktif dalam Program Pemberdayaan Masyarakat Melalui Ternak Domba di Kampoeng Ternak Nusantara belum efektif.

\section{Hipotesis Efektivitas Pendayagunaan Zakat Produktif}

Pada sub bab ini peneliti membuat hipotesis yang ditujukan bagi lima variabel penelitian melihat dari rata-rata persentase keseluruhan variabel jika digabungkan. Dan untuk menjawab rumusan masalah yang ada, yaitu:

Ho $: \mu \geq 75 \%$ Ho diterima atau tidak ditolak, yang berarti bahwa pendayagunaan zakat produktif dalam Program Pemberdayaan Masyarakat Melalui Ternak Domba di Kampoeng Ternak Nusantara sudah berjalan efektif.

H1 $: \mu<75 \%$ H1 ditolak, yang berarti bahwa pendayagunaan zakat produktif dalam Program Pemberdayaan Masyarakat Melalui Ternak Domba di Kampoeng Ternak Nusantara belum efektif.

\section{BAB 4 EFEKTIFITAS PENDAYAGUNAAN ZAKAT PRODUKTIF DALAM PROGRAM PEMBERDAYAAN MASYARAKAT}

\subsection{Analisis}

Responden dalam penelitian ini adalah anggota yang telah mengikuti program pemberdayaan peternak di Wilayah Sukabumi. Jumlah responden sebanyak 73 orang dengan karakteristik responden Sebagai berikut:

Tabel 0.1 Usia Anggota

\begin{tabular}{|l|l|l|}
\hline Usia & Jumlah & Persentase \\
\hline$<20$ & 1 & $1,4 \%$ \\
\hline $20-29$ & 6 & $8 \%$ \\
\hline $30-39$ & 17 & $23 \%$ \\
\hline $40-49$ & 31 & $43 \%$ \\
\hline $50-<60$ & 18 & $25 \%$ \\
\hline Total & 73 & $100 \%$ \\
\hline
\end{tabular}

Sumber: Kampoeng Ternak Nusantara, diolah (2012)

Dari tabel 4.2 di atas menggambarkan bahwa anggota Kampoeng Ternak Wilayah Sukabumi yang berusia >20 tahun hanya berjumlah 1 anggota (1 \%), sedangkan anggota yang berumur antara 20-29 tahun 
berjumlah 6 anggota (8\%), sedangkan anggota yang berumur antara 30-39 tahun berjumlah 17 anggota (23\%), sedangkan anggota yang berumur diantara 40-49 berjumlah 31 anggota (43\%), dan yang berumur diantara $50-<60$ berjumlah 18 anggota $(25 \%)$. Dengan melihat persentase diatas maka anggota terbanyak pada kisaran umur 40-49 orang.

Tabel 0.2 Jenis Kelamin

\begin{tabular}{|l|l|l|l|}
\hline Jenis kelamin & Laki-laki & Perempuan & Total \\
\hline Jumlah & 69 & 4 & 73 \\
\hline Persentase & $95 \%$ & $5 \%$ & 100 \\
\hline
\end{tabular}

Sumber: Kampoeng Ternak Dompet Dhuafa, Diolah (2012)

Tabel di atas menggambarkan jenis kelamin anggota Kampoeng Ternak Dompet Dhuafa di Wilayah Sukabumi. Dapat terlihat sebagian besar mitra berjenis kelamin laki-laki yaitu berjumlah 69 Anggota (95\%), sedangkan anggota yang berjenis kelamin perempuan berjumlah 4 Anggota (5\%). Dari data diatas mayoritas peternak adalah laki-laki sedangkan wanita hanya sebagian kecil. Hal ini dikarenakan profesi peternak memang lebih banyak dilakukan oleh lelaki karena memang pengorbanan yang dilakukan saat berternak sangatlah berat. Karena dalam beternak tidak hanya keahlian saja yang dibutuhkan akan tetapi tenaga yang diperlukanpun sangatlah besar. Terlebih saat mencari pakan ternak. Ibu-ibu yang menjadi peternak ini dikarenaka untuk membantu dan mencari tambahan pendapatan keluarga.

Tabel 0.3 Tingkat Pendidikan

\begin{tabular}{|l|c|c|c|c|c|c|}
\hline Pendidikan & SD/MD & SMP & SMA & D3 & Sarjana & Total \\
\hline Jumlah & 62 & 6 & 3 & 1 & 1 & 73 \\
\hline Persentase & 85 & 8 & 4 & 2 & 1 & 100 \\
\hline
\end{tabular}

Sumber: Kampoeng Ternak Dompet Dhuafa , Diolah (2012)

Dari tabel 4.4 di atas, menggambarkan mayoritas dari mitra Kampoeng Ternak tingkat pendidikannya adalah SD sebanyak 62 anggota (85\%), dan SMP sebanyak 6 angggota (8\%), SMA sebanyak 3 anggota (4\%), D3 sebanyak 1 angggota (2\%) dan Sarjana sebanyak 1 anggota( $1 \%)$. Artinya sebagian besar anggota berpendidikan SD hal ini harus menjadi perhatian lebih bagi Lembaga Kampoeng Ternak ketika melakukan pendampingan terhadap anggota. Agar anggota dapat memahami secara jelas tahapan program dan pelatihan yang diterima oleh mitra. Koresponden pengisian kuisioner dari 73 anggota yang ada, sebanyak 47 orang bisa mengisi kuisisoner. Sedangkan data pendapatan seluruh mitra dapat dianalisa sebanyak 47 anggota yang mengikuti program pemberdayaan peternak. 


\subsubsection{Analisis Kuantitatif}

\section{a. Hasil Uji Validitas}

Dari hasil perhitungan uji validitas 16 pertanyaan yang diajukan terhadap responden dari mitra Kampoeng Ternak Wilayah Sukabumi dengan skor totalnya adalah sebagai berikut:

Tabel 0.4 Uji Validitas

\begin{tabular}{|l|l|l|l|}
\hline Pertanyaan & R Hitung & R Tabel & Kesimpulan \\
\hline Pertanyaan 1 & 0,440 & 0,2876 & Valid \\
\hline Pertanyaan 2 & 0,352 & 0,2876 & Valid \\
\hline Pertanyaan 3 & 0,429 & 0,2876 & Valid \\
\hline Pertanyaan 4 & 0,552 & 0,2876 & Valid \\
\hline Pertanyaan 5 & 0,386 & 0,2876 & Valid \\
\hline Pertanyaan 6 & 0,336 & 0,2876 & Valid \\
\hline Pertanyaan 7 & 0,385 & 0,2876 & Valid \\
\hline Pertanyaan 8 & 0,364 & 0,2876 & Valid \\
\hline Pertanyaan 9 & 0,290 & 0,2876 & Valid \\
\hline Pertanyaan 10 & 0,242 & 0,2876 & Tidak Valid \\
\hline Pertanyaan 11 & 0,457 & 0,2876 & Valid \\
\hline Pertanyaan 12 & 0,490 & 0,2876 & Valid \\
\hline Pertanyaan 13 & 0,002 & 0,2876 & Tidak Valid \\
\hline Pertanyaan 14 & 0,637 & 0,2876 & Valid \\
\hline Pertanyaan 15 & 0 & 0,2876 & Tidak Valid \\
\hline Pertanyaan 16 & 0 & 0,2876 & Tidak Valid \\
\hline
\end{tabular}

Dari data di atas tergambarkan bahwa dari 16 pertanyaan yang diberikan terdapat 4 pertanyaan atau variabel yang tidak valid. Dalam hal ini ditandai dengan $\mathrm{R}$ Hitung dari penghitungan uji validitas yang telah dilakukan berada dibawah atau kurang dari $\mathrm{R}$ tabel $(0,2876)$. Sehingga untuk melakukan uji reabilitas data yang tidak valid tidak digunakan.

Tabel 0.5 Uji Validitas

\begin{tabular}{|l|l|l|l|}
\hline Pertanyaan & R Hitung & R Tabel & Kesimpulan \\
\hline Pertanyaan 1 & 0,440 & 0,2876 & Valid \\
\hline Pertanyaan 2 & 0,352 & 0,2876 & Valid \\
\hline Pertanyaan 3 & 0,429 & 0,2876 & Valid \\
\hline Pertanyaan 4 & 0,552 & 0,2876 & Valid \\
\hline Pertanyaan 5 & 0,386 & 0,2876 & Valid \\
\hline Pertanyaan 6 & 0,336 & 0,2876 & Valid \\
\hline Pertanyaan 7 & 0,385 & 0,2876 & Valid \\
\hline Pertanyaan 8 & 0,364 & 0,2876 & Valid \\
\hline Pertanyaan 9 & 0,290 & 0,2876 & Valid \\
\hline Pertanyaan 10 & 0,457 & 0,2876 & Valid \\
\hline Pertanyaan 11 & 0,490 & 0,2876 & Valid \\
\hline Pertanyaan 12 & 0,637 & 0,2876 & Valid \\
\hline
\end{tabular}


Data di atas adalah daftar hasil uji validitas yang dinyatakan valid dan yang tidak valid sebanyak 4 pertanyaan pada nomor $10,13,15$ dan 16 dengan pembahasan nomor 10 adalah, "Para peternak mampu menjual langsung atau melalu jaringan yang telah dibuat oleh lembaga", dan pada nomor 13, "Peternak mampu meningkatkan tingkat spiritual mereka", dan nomor 15, "Peternak mampu berperan aktif dalam pembangunan Koperasi Riung Mukti", dan terakhir nomor 16, "Koperasi Riung Mukti mampu menjadi penghubung antara peternak dengan Lembaga Kampoeng Ternak Nusantara”.

\section{b. Hasil Uji Reabilitas}

Setelah dilakukan uji validitas, maka peneliti akan melanjutan dengan uji reabilitas dengan menggunakan Cronbach's Alpha setelah sebelumnya membuang data yang tidak valid maka hasilnya sebagai berikut:

\section{Tabel 0.6 Hasil Uji Reabilitas}

Reliability Statistics
\begin{tabular}{|l|l|}
\hline Cronbach's Alpha & N of Items \\
\hline .607 & 12 \\
\hline
\end{tabular}

Uji reabilitas dilakukan untuk menguji pertanyaan-pertanyaan pada kuisioner yang telah diberikan kepada responden, dengan cara membandingkan nilai $r$ hitung dengan nilai $r$ tabel. Hasil dari uji reabilitas yang dilakukan dengan menggunakan Cronbach Alpha adalah r hitung sebesar 0,607 sedangkan $r$ tabel sebesar 0,2876. Dari hasil tersebut menghasilkan $r$ hitung lebih besar dari $r$ tabel dan ini memberikan arti bahwa pertanyaan-pertanyaan kuisioner dinyatakan reliable, artinya pertanyaan-pertanyaan tersebut dapat menghasilkan data-data yang konsisten bila digunakan beberapa kali untuk mengukur objek yang sama.

\section{c. Analisis Uji Statistik Non Parametrik Wilxocon Signed Rank Test}

Pada sub bab kali ini peneliti akan melakukan uji test statistic Wilcoxon untuk mengetahui tingkat perubahan pendapatan sebelum diadakannya program pendayagunaan zakat produktif pada Program Pemberdayaan Masyarakat Melalui Ternak Domba dengan sesudah program tersebut. Peneliti melakukan uji wilcoxon dengan menggunakan bantuan SPSS 18.0 for windows. Setelah dilakukan uji maka peneliti mendapatkan hasil sebagai berikut: 
Tabel 0.7 Hasil Uji Wilcoxon

Test Statisticsb

\begin{tabular}{|c|c|}
\hline & $\begin{array}{l}\text { sesudah program } \\
\text { - sebelum } \\
\text { program }\end{array}$ \\
\hline $\begin{array}{l}\mathrm{Z} \\
\text { Asymp. Sig. (2-tailed) }\end{array}$ & $\begin{array}{l}-5.970 \mathrm{a} \\
.000\end{array}$ \\
\hline
\end{tabular}

a. Based on negative ranks.

b. Wilcoxon Signed Ranks Test

Hasil uji statistik wilxocon diperoleh nilai z hitung adalah -5.970 dengan tingkat signifikasi perubahan kedua data didapat nilai sig. 0.000, hal ini menunjukkan bahwa nilai signifikan $<\alpha$. Dan nilai $\mathrm{z}$ tabel dengan $\alpha=5 \%$ untuk uji dua sisi (2-tailed) $=1,645$. Maka diperoleh $\mathrm{z}$ hitung $5.970<-1.645$ dan nilai sig $<\alpha$. maka hasilnya adalah $\mathrm{H} 1$ diterima : yang menyatakan bahwa telah terjadi perubahan pada peningkatan pendapatan mitra setelah mengikuti program pendayagunaan zakat produktif dalam Program Pemberdayaan Masyarakat Melalui Ternak Domba di wilayah Sukabumi. Perubahan kenaikan pendapatan ini menunjukkan pada perubahan positif. Dapat dilihat dari hasil uji SPSS 18.0 berikut ini:

Ranks

Tabel 0.8 Hasil Uji Wilcoxon Pendapatan Sesudah dan Sebelum

\section{Program}

\begin{tabular}{|ll|l|l|l|}
\hline & $\mathrm{N}$ & Mean Rank & Sum of Ranks \\
\hline sesudah program - sebelum & Negative Ranks & $0 \mathrm{a}$ & .00 & .00 \\
program & Positive Ranks & $47 \mathrm{~b}$ & 24.00 & 1128.00 \\
& Ties & $0 \mathrm{c}$ & & \\
& Total & 47 & & \\
\hline
\end{tabular}

a. sesudah program $<$ sebelum program

b. sesudah program $>$ sebelum program

c. sesudah program $=$ sebelum program

Hasil Uji wilcoxon pada output SPSS diambil dari $n=47$ mitra yang tergabung dalam program pemberdayaan peternak. Output diatas menggambarkan peningkatan pendapatan sebelum dan sesudah program, dengan perolehan nilai positive ranks seluruh mitra yang tergabung dalam program yaitu 47 mitra. Hal ini menunjukkan bahwa 47 mitra yang mengikuti program ini mengalami peningkatan pendapatan. Data rata-rata pendapatan sebelum program pemberdayaan masyarakat adalah sebesar Rp.734.531 sedangkan data rata-rata pendapatan setelah menerima zakat produktif adalah sebesar Rp.945.055. (lampiran pada Uji Wilcoxon pada peningkatan pendapatan). 


\section{d. Analisis Hipotesis}

Pada sub bab ini peneliti akan melakukan analisis terhadap hipotesis dari masing-masing variabel yang menjadi indikator efektivitas pendayagunaan zakat produktif dalam program pemberdayaan masyarakat melalui ternak domba. Peneliti akan melakukan analisa hipotesis melalui data yang telah peneliti olah dari hasil kuisioner dan uji statistik wilcoxon untuk mengetahui peningkatan pendapatan. Selain itu peneliti memperkuat hasil olah data tersebut dengan menjelaskan melalui hasil observasi dan wawancara yang telah dilakukan di Wilayah Sukabumi Kecamatan Kelapa Nunggal. Berikut penjelasannya:

\subsection{Peningkatan Pendapatan}

Untuk mengetahui peningkatan pendapatan yang terjadi pada anggota yang tergabung dalam program pemberdayaan masyarakat. Peneliti memiliki dua hasil uji, yaitu melalui hasil kuisioner dan hasil uji statistik wilcoxon untuk menjawab dua hipotesis:

1. Efektivitas Program sama atau diatas $75 \%$

Hipotesis yang pertama yaitu untuk menjawab efektivitas program pemberdayaan masyarakat dengan variabel peningkatan pendapatan, dengan tolak ukur sama atau lebih besar dari 75\%. Dengan hipotesis sebagai berikut:

Ho $: \mu \geq 75 \%$ Ho diterima atau tidak ditolak, yang berarti bahwa pendayagunaan zakat produktif dalam Program Pemberdayaan Masyarakat Melalui Ternak Domba di Kampoeng Ternak Nusantara sudah efektif.

H1 $: \mu<75 \%$ H1 ditolak yang berarti bahwa pendayagunaan zakat produktif dalam Program Pemberdayaan Masyarakat Melalui Ternak Domba di Kampoeng Ternak Nusantara belum efektif.

Hasil dari nilai mean variabel peningkatan pendapatan ini adalah sebesar $73,73 \%$. Artinya peningkatan pendapatan pada program pemberdayaan masyarakat belum efektif atau masih belum mencapai target yang diharapkan dengan persentase sama atau lebih besar dari $75 \%$. Akan tetapi pada dasarnya, melalui program ini, anggota telah mengalami peningkatan pendapatan. Untuk itu peneliti membuktikan dengan melakukan uji statistik wilcoxon dengan membandingkan pendapatan sebelum dan sesudah program pemberdayaan masyarakat dengan hipotesis sebagai berikut:

\section{Peningkatan Pendapatan Melalui Uji Wilcoxon}

Ho : Tidak terjadi perubahan peningkatan pendapatan pada mitra melalui Program Pemberdayaan Masyarakat Melalui Ternak Domba di Kampoeng Ternak Nusantara. 
H1 : Terjadi perubahan peningkatan pendapatan pada mitra melalui Program Pemberdayaan Masyarakat Melalui Ternak Domba di Kampoeng Ternak Nusantara.

Dari hasil uji tersebut, menyatakan bahwa $\mathrm{H} 1$ diterima atau telah terjadi peningkatan pendapatan pada anggota sesudah program tersebut. Dengan rata-rata pendapatan sebesar Rp. 945.055. hal ini membuktikan bahwa setelah mengikuti program pemberdayaan masyarakat terjadi peningkatan pendapatan terhadap anggota. Peningkatan yang terjadi memang belum signifikan dari pendapatan sebelum program dengan ratarata sebesar Rp.734.531.

\subsection{Peningkatan Kesejahteraan dan Peningkatan Aset Produktif}

Variabel yang kedua ini memiliki keterkaitan erat dengan variabel yang pertama. Karena pada dasarnya, ketika peningkatan pendapatan sudah meningkat maka akan terjadi peningkatan kesejahteraan dan peningkatan aset yang dimiliki oleh anggota. Hipotesis variabel yang kedua ini adalah sebagai berikut:

Ho $\quad: \mu \geq 75 \%$ Ho diterima atau tidak ditolak, yang berarti bahwa telah terjadi Peningkatan Kesejahteraan dan Peningkatan Aset Produktif melalui program pendayagunaan zakat produktif dalam Program Pemberdayaan Masyarakat Melalui Ternak Domba di Kampoeng Ternak Nusantara sudah efektif.

H1 : $\mu<75 \%$ H1 ditolak yang berarti bahwa. tidak terjadi Peningkatan Kesejahteraan dan Peningkatan Aset Produktif melalui program pendayagunaan zakat produktif dalam Program Pemberdayaan Masyarakat Melalui Ternak Domba di Kampoeng Ternak Nusantara belum efektif.

Hasil nilai persentase yang didapat adalah sebesar 77, 3 persen. Hasil ini menandakan bahwa Ho diterima, atau tingkat persentase yang dihasilkan lebih besar dari 75\%. Hal ini menggambarkan bahwa program pemberdayaan masyarakat telah berjalan efektif sehingga terjadi peningkatan kesejahteraan dan peningkatan aset pada anggota yang mengikuti program pemberdayaan masyarakat.

\section{Terbangunnya kemandirian dalam diri peternak}

Terbangunnya kemandirian dalam diri peternak ini adalah gambaran dari baiknya pembinaan dan pendampingan yang dilakukan oleh Lembaga Kampoeng Ternak Dompet Dhuafa. Dari proses pendampingan ini peternak mendapatkan berbagai macam training, baik itu motivasi dan teknik pengembangan usaha. Variabel ini memiliki hipotesis sebagai berikut:

Ho $: \mu \geq 75 \%$ Ho diterima atau tidak ditolak, yang berarti bahwa telah terjadi kemandirian dalam diri peternak untuk melakukan usaha ternaknya melalui program pendayagunaan zakat produktif dalam 
Program Pemberdayaan Masyarakat Melalui Ternak Domba di Kampoeng Ternak Nusantara sudah efektif.

H1 : $\mu<75 \%$ H1 ditolak yang berarti bahwa. tidak terjadi kemandirian dalam diri peternak untuk melakukan usaha ternaknya melalui program pendayagunaan zakat produktif dalam Program Pemberdayaan Masyarakat Melalui Ternak Domba di Kampoeng Ternak Nusantara belum efektif.

Hasil persentase bagi variabel terbangunnya kemandirian ini adalah sebesar $74,25 \%$. Persentase tersebut menyatakan bahwa variabel terbangunya kemandirian dalam diri peternak belum efektif. Dalam variabel ini terdapat satu indikator yang pertanyaannya dianggap tidak valid yang berbunyi "Para peternak mampu menjual langsung atau melalui jaringan yang telah dibuat oleh lembaga".

\section{Peningkatan Etos Kerja dan Spiritual}

Variabel peningkatan etos kerja dan spiritual adalah salah satu bagian terpenting dari adanya pendampingan yang dilakukan oleh Lembaga Kampoeng Ternak Dompet Dhuafa. Faktor spiritual dalam variabel ini tidak hanya menitik beratkan peningkatan mutu beribadah peternak. Tetapi melalui budaya kerja yang Islami yang diterapkan dalam program pemberdayaan masyarakat. Hipotesis dari variabel ini adalah sebaga berikut:

Ho $\quad: \mu \geq 75 \%$ Ho diterima atau tidak ditolak, yang berarti bahwa telah terjadi peningkatan etos kerja dan tingkat spiritual melalui program pendayagunaan zakat produktif dalam Program Pemberdayaan Masyarakat Melalui Ternak Domba di Kampoeng Ternak Nusantara sudah efektif.

H1 : $\mu<75 \%$ H1 ditolak yang berarti bahwa. tidak terjadi peningkatan etos kerja dan tingkat spiritual melalui program pendayagunaan zakat produktif dalam Program Pemberdayaan Masyarakat Melalui Ternak Domba di Kampoeng Ternak Nusantara belum efektif.

Variabel penelitian ini memiliki tingkat persentase sebesar 81,7\%. Sehingga Ho diterima. Atau variabel peningkatan etos kerja dan spiritual dalam diri anggota setelah mengikuti program pemberdayaan ini telah efektif. Peningkatan ini menandakan bahwa proses pendampingan telah diaplikasikan baik untuk menigkatkan etos kerja mereka dan juga peningkatan spiritual mereka. Karena untuk meningkatkan kesejahteraan anggota, anggota dituntut untuk bekerja keras, bekerja secara professional, dan bekerja dengan jujur serta amanah. 


\section{Kemandirian Kelembagaan}

Variabel kemandirian kelembagaan ini diterapkan untuk mengetahui bagaimana peran anggota dalam membagun Koperasi Riung Mukti. Hipotesis dari variabel ini adalah sebagai berikut:

Ho : $\mu \geq 75 \%$ Ho diterima atau tidak ditolak, yang berarti bahwa telah terjadi kemandirian kelembagaan pada Koperasi Riung Mukti setelah melalui program pendayagunaan zakat produktif dalam Program Pemberdayaan Masyarakat Melalui Ternak Domba di Kampoeng Ternak Nusantara sudah berjalan efektif.

H1 $: \mu<75 \%$ H1 ditolak yang berarti bahwa. tidak terjadi kemandirian kelembagaan pada Koperasi Riung mukti setelah melalui program pendayagunaan zakat produktif dalam Program Pemberdayaan Masyarakat Melalui Ternak Domba di Kampoeng Ternak Nusantara belum efektif.

Dalam variabel penelitian ini, pertanyaan kuisioner yang diajukan dianggap tidak valid setelah dilakukan uji validitas. Akan tetapi peneliti menghitung nilai persentase melalui program Microsoft Office Excel , hasilnya adalah $75 \%$ sama dengan tingkat persentase yang telah ditentukan hal ini menandakan bahwa Ho diterima atau variabel kemandirian dianggap telah efektif. Jika melihat uji validitas tersebut maka peneliti belum dapat memberikan kesimpulan apakah variabel ini telah berjalan efektif atau belum efektif.

\section{Hipotesis Efektivitas Pendayagunaan Zakat Produktif}

Pada hipotesis pendayagunaan zakat produktif melalui program pemberdayaan masyarakat melalui ternak domba, peneliti membuat hipotesis yang ditujukan bagi lima variabel penelitian dilihat dari rata-rata persentase keseluruhan variabel jika digabungkan. Dan untuk menjawab rumusan masalah yang ada, hipotesisnya sebagai berikut:

Ho $\quad: \mu \geq 75 \%$ Ho diterima atau tidak ditolak, yang berarti bahwa pendayagunaan zakat produktif dalam Program Pemberdayaan Masyarakat Melalui Ternak Domba di Kampoeng Ternak Nusantara sudah berjalan efektif.

H1 : $\mu<75 \%$ H1 ditolak yang berarti bahwa pendayagunaan zakat produktif dalam Program Pemberdayaan Masyarakat Melalui Ternak Domba di Kampoeng Ternak Nusantara belum efektif.

Persentase rata-rata keseluruhan variabel ini adalah sebesar $76,74 \%$. Artinya Ho diterima atau program pendayagunaan zakat produktif telah berjalan efektif. Akan tetapi, program pemberdayaan masyarakat ini masih harus terus ditingkatkan. Terlebih lagi dari sektor kelembagaan pada Koperasi Riung Mukti. 


\subsection{Pengujian Hipotesis}

Selanjutnya peneliti akan melakukan pengujian terhadap Hipotesis yang telah ditentukan. setelah sebelumnya dilakukan pengujian

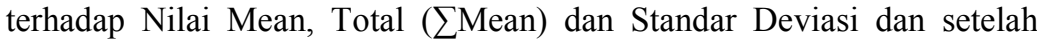
dijelaskan secara rinci masing-masing variabel. Pengujian hipotesis ini untuk mengetahui apakah asumsi bahwa efektivitas pendayagunaan zakat produktif pada program pemberdayaan peternak domba di Kampoeng Ternak Nusantara sama dengan atau lebih besar dari $75 \%$ dapat diterima atau tidak dengan hipotesis sebagai berikut:

Ho $\quad: \mu \geq 75 \%$ Ho diterima atau tidak ditolak

$$
\mu \geq 75 \%=0.75 \times 47=35.25 \text { (Rata-Rata Ideal) }
$$

yang berarti bahwa pendayagunaan zakat produktif dalam Program Program Pemberdayaan Masyarakat Melalui Ternak Domba di Kampoeng Ternak Nusantara sudah efektif.

H1 $: \mu<75 \%$ H1 ditolak

$$
\mu \geq 75 \%=0.75 \times 47=35.25 \text { (Rata-Rata Ideal) }
$$

yang berarti bahwa pendayagunaan zakat produktif dalam Program Program Pemberdayaan Masyarakat Melalui Ternak Domba di Kampoeng Ternak Nusantara tidak efektif.

Untuk melakukan uji hipotesis di atas maka rumus yang digunakan adalah t-test one sample dengan uji pihak kiri yang digunakan apabila: Hipotesis no (Ho) berbunyi" lebih besar atau sama dengan $(\geq)$ " dan hipotesis alternatifnya berbunyi "lebih kecil $(<)$ ". (Sugiyono, 2012, p. 99) dengan rumus sebagai berikut:

$$
\mathrm{t}=\frac{36,88-35,25}{(1,907 / \sqrt{47})}=\frac{1,63}{0,28}=34,45
$$

Jadi nilai t hitung adalah 5.821

Untuk mengetahui apakah hipotesis tersebut diterima atau ditolak, maka nilai dari $\mathrm{t}$ hitung dibandingkan dengan nilai $\mathrm{t}$ table. Dengan ketentuan nilai $\mathrm{t}$ hitung $\geq$ dari nilai $\mathrm{t}$ tabel maka Ho diterima, begitu pula sebaliknya. Untuk mendapatkan nilai $t$ tabel dengan menggunakan $\mathrm{df}=\mathrm{n}-1$ sehingga $\mathrm{df}=47-1=46$. Pada tingkat kesalahan $(\alpha)$ $5 \%$, maka diperoleh $\mathrm{t}$ tabel $=1.671$.

Hasilnya $\mathrm{t}$ hitung (5.821) > dari pada t tabel (1.671), maka dengan hasil tersebut Ho diterima, yang artinya bahwa asumsi efektivitas pendayagunaan zakat produktif pada program pemberdayaan peternak di Kampoeng Ternak wilayah Sukabumi $\geq 75 \%$ adalah benar atau diterima. Dan ini menandakan bahwa program tersebut sudah berjalan dengan efektif. Dan berdasarkan data analisis mean yang dipaparkan pada tabel 4.12 dapat diketahui bahwa tingkat efektivitas pendayagunaan zakat produktif pada program pemberdayaan peternak domba di Kampoeng Ternak Nusantara wilayah Sukabumi adalah sebesar 76, 74\%. Secara keseluruhan program pendayagunaan zakat produktif melalui program pemberdayaan masyarakat melalui ternak domba telah berjalan efektif. Akan tetapi, pengembangan serta inovasi harus terus dilakukan untuk peningkatan usaha anggota. Peran aktif anggota akan seimbang jika 
Koperasi dapat terus memberikan kontribusi positif dengan memberikan peluang- peluang usaha melalui kerjasama dengan pihak luar atau lembaga lainnya. Terlebih lagi setelah berkerjasama dengan PT. Chevron Koperasi Riung Mukti memiliki peluang yang besar untuk berkembang dan mengembangkan rencana jangka panjangnya yaitu Proyek Peternakan Terpadu.

\section{Penutup}

Berdasarkan uraian pada pembahasan dan analisis yang telah dilakukan pada bab empat. maka pada bab ini penulis akan mengambil kesimpulan dari hasil analisis tersebut sehingga dapat menjawab dari rumusan masalah yang ada, yaitu bagaimana efektivitas pendayagunaan zakat produktif pada program pemberdayaan masyarakat melalui ternak domba di Lembaga Kampoeng Ternak Nusantara. Dalam penelitian ini terdapat lima variabel yang menjadi indikator yaitu variabel peningkatan pendapatan, peningkatan kesejahteraan dan peningkatan aset, kemandirian dalam diri peternak, peningkatan etos kerja dan spiritual dan kemandirian kelembagaan.

Berdasarkan penelitian yang dilakukan dengan berbagai pihak yang memiliki peran penting dalam program pemberdayaan masyarakat yaitu bagian program dan sumber daya manusia Kampoeng Ternak Dompet Dhuafa, Ketua Koperasi Riung Mukti, Ketua Kelompok Peternak, dan mitra kampoeng ternak. Maka program pendayagunaan zakat produktif pada program pemberdayaan masyarakat di wilayah Sukabumi melalui ternak domba telah berjalan efektif. Hal ini menunjukkan bahwa melalui program pemberdayaan masyarakat telah terjadi perubahan yang baik. Baik itu dalam hal peningkatan pendapatan, pengembangan usaha ternak, dan pengembangan jaringan usaha yang bekerjasama dengan PT Chevron.

\section{DAFTAR PUSTAKA}

Al Quran Sahmalnour. (2009). Bogor: Sahmalnour.

Ali, M.D.. (2006). Sistem Ekonomi Islam Zakat dan Wakaf. Jakarta: Universitas Indonesia Press.

Al Syaikh. Yasin Ibrahim, (2008) Kitab Zakat: Hukum, Tata Cara dan Sejarah. Bandung: Marja.

Antonio, Muhammad Syafi'I. (1999) Bank Syariah Bagi Bankir dan Praktisi Keuangan. Jakarta: IB dan Tazkia Institute.

Asnaini. (2008). Zakat Produktif dalam Prespektif Hukum Islam. Jakarta: R. Raniry Press.

Bariadi, Lili, Muhammad Zen, M. Hudri. (2006). Zakat dan Wirausaha. Jakarta: Center For Enterpreneurship.

Hafidhhuddin, D.. (2012). Manajemen Zakat Indonesia. Jakarta: Forum Zakat. 
Hafidhuddin, D.. (2002). Zakat dalam Pembangunan Perekonomian Moderen. Jakarta: Gema Insani.

Hafidhuddin, D.. (2006, November). Zakat Sebagai Tiang Utama Ekonomi Syari'ah. Jakarta: Masyarakat Ekonomi Syari'ah (MES).

Hikam, D..(2004). Pendayagunaan Zakat Untuk Usaha Produktif. Jakarta: Pasca Uin Syarif Hidayatullah, 2004.

Karim, A. A.. (2010). Ekonomi Mikro Islam. Jakarta: Grafindo Persada.

Megawati. (2011). Efektifitas Pendayagunaan Zakat pada Program Ketahanan Pangan Ubi (KPU). Jakarta: STEI SEBI.

Menggagas Arsitektur Zakat Nasional: Menuju Sinergi Pemerintah dan Masyarakat Sipil dalam Pengelolaan Zakat Nasional. (2010) Ciputat: Indonesia Magnificence of Zakat.

Membangun Peradaban Zakat Indonesia: Soal Kebijakan dan Hal Lain yang Belum Paripurna. (2012). Ciputat: Indonesia Magnificence of Zakat.

Mila.S.. (2008, Juni). Pengaruh Pendayagunaan Zakat Produktif terhadap Pemberdayaan Mustahiq Pada Laz Yayasan Solo Peduli Surakarta. Jakarta: Voll 2 La_ Riba

Mufraini, M. A.. (2006) Akuntansi dan Manajemen Zakat. Jakarta: Kencana Prenada Media Group.

Qardhawi, Y.. (1987). Hukum Zakat. Jakarta: Pustaka Lentera Nusa.

Rai, I.G.A.. (2008). Audit Kinerja Pada Sektor Publik. Jakarta: Salemba Empat.

Sangadji \& Etta M.S.. (2010). Metodelogi Penelitian. Yogyakarta: Andi Offset.

Sugiyono. (2009). Metodelogi Penelitian Bisnis. Bandung: Alfabeta.

Sugiyono. (2009). Metodelogi Penelitian Kuantitatif Kualitatif dan R\&D. Bandung: Alfabeta.

Sugiyono. (2011). Penelitian Kombinasi. Bandung: Alfabeta.

Sugiyono. (2012). Statistik untuk Penelitian. Bandung: Alfabeta.

Sunyoto, D.. (2011). Metodelogi Penelitian Ekonomi. Jakarta: CAPS.

Trianto, A..(2007). Analisis Efektifitas Penerapan Pembiayaan Murobahah pada Lembaga Multifinance. Jakarta: STEI SEBI.

Wasilah, S.N.. (2009) Akuntansi Syariah di Indonesia. Jakarta: Salemba Empat.

Zakat dan Pembangunan: Pembangunan Era Baru Zakat Menuju Kesejahteraan Ummat.(2009). Ciputat: Indonesia Magnificence of Zakat.

Zuhayly, DR.W..(2008) Zakat Kajian Berbagai Mazhab. Bandung: PT. Remaja Rusdakarya. 